\title{
Modeling of support system for preventing retrogressive slide of Ambarl 1 landslide in Avcrlar district, Istanbul
}

\section{İstanbul, Avcılar İlçesi Ambarlı heyelanının gerilemesini önlemeye yönelik iksa sistemi modellemesi}

\author{
Ibrahim KUSSKU ${ }^{1^{*}}$ (D) , Süleyman DALGIÇ² \\ 1,2Department of Geological Engineering, Faculty of Engineering, Istanbul University-Cerrahpasa, Istanbul, Turkey. \\ ibrahim@istanbul.edu.tr, dalgic@istanbul.edu.tr
}

\section{Abstract}

Disaster-prone area is declared as already affected or may be affected by the disasters that have been occurred or are likely to occur in the disaster survey reports. In addition, these areas should be considered to be rehabilitated for technically or economically reasons by means of improvement studies. However, the future impact of the landslide on the settlements located at the boundary of the area determined according to this definition is sometimes not evaluated. Ambarl Landslide Area located in Istanbul, Avcllar was declared a disaster-prone area in 2005. In the area, 56 buildings became out of use and all the buildings in the area were demolished due to the related regulation. However, during the ongoing process, monitoring studies were not conducted in the area. The landslide situation was left uncontrolled within this period, and risks to which the near structures might be affected were not evaluated. In this study, it is aimed to evaluate the potential of growth of The Landslide Area and the current security conditions in the nearby structures. Previous studies in the field were evaluated and new boreholes were drilled. Index and mechanical characteristics of the soil samples were tested within the scope of the study. Inclinometer measurements were made for 6 months, sliding planes were determined and velocities were calculated for the active landslide. For the current situation, despite the risks determined by static and dynamic stability analyzes, taking into account the structural loads in the impact area, the cantilever type shoring system was modeled, and the safety conditions for the north of the area were defined.

Keywords: Disaster, Landslide, Stability analyzes, Bored pile.
Öz

Afete Maruz Bölge, özetle; afet etüt raporlarında, olmuş veya olması muhtemel afetlerden etkilendiği veya etkilenebileceği belirtilen, iyileștirme çalıșmaları ile teknik ya da ekonomik olarak ıslah edilmesi mümkün olmayan alanlar olarak tanımlanabilir. Ancak, heyelanın, bu tanıma göre belirlenen alan sinırında bulunan yerleșim yerlerine etkisi kimi zaman tartışmadan uzak kalmaktadır. İstanbul Avcllar Ambarl Heyelanı ve çevresi, bu tip bir alan olup, heyelan alanı 2005 yılında Afete Maruz Bölge ilan edilmiştir. Alanda, 56 adet yapı kullanılmaz hale gelmiş ve karar gereği alandaki tüm yapılar yıkılmıştır. Ancak, devam eden süreçte, alanda herhangi bir hareket izleme çalıșması yapılmamıștır. Böylelikle, heyelanın zaman içerisindeki durumu kontrolsüz bırakılmıș ve çevre yapıların süreç içinde karşılaşabilecekleri riskler değerlendirilmemiş̧tir. Bu çalışmada, Avcılar Ambarlı Heyelanı alanının, gerileyerek büyüme potansiyelinin ve mevcut durumda çevre yapılardaki güvenlik koşullarının ortaya konulması amaçlanmıștır. Alanda yapılan önceki çalışmalar değerlendirilmiș, çalıșma kapsamında yeni zemin araștırma sondajları ile indeks ve mekanik laboratuvar deneyleri yapılmıștır. Sondajlarda 6 ay süreyle inklinometre ölçümü yapılmıs, kayma düzlemleri tespit edilmiş ve aktif olarak hareketine devam ettiği belirlenen heyelanın kayma hızları hesaplanmıștır. Mevcut durum için, etki alanındaki yapı yükleri de hesaba katılarak yapılan statik ve dinamik stabilite analizleri ile belirlenen risklere karşın, konsol tip forekazık sistemi modellenmiş ve heyelanın gerileyeceği alan için elde edilen güvenlik koşulları tanımlanmıştır.

Anahtar kelimeler: Afet, Heyelan, Stabilite analizi, Fore kazık.

\section{Introduction}

Due to landslide disaster occurred in Ambarlı district of the Avcllar town of Istanbul city, which was identified by [1] has been declared as a "Disaster-Prone Area" by the 28.06.2005 dated and 2005/9109 numbered regulation of the Council of Ministers. The buildings within the disaster-prone area were demolished at various times and the area was clear of residential buildings. In the following studies, fractures and partial collapses were observed on the walls and roads in the northern border of disaster-prone area and this event has been considered as a threat for the nearby buildings. In the region, loading on the crown, one of the landslide-triggering parameters, is continuing and no measure has been taken for groundwater level change and no earthquake danger with high ground acceleration was considered [2]. In this study, movement of landslide is investigated using field and laboratory data and necessary precautions are discussed. For this reason, borehole, laboratory data, groundwater measurements and inclinometer measurement (for determination of slip planes) were utilized. During the preparation of study, two main data were utilized. The first data set was from [1] and secondary data were compiled during the course of present work. Regarding the first data set, landslide potential of the area was studied utilizing a number of 25 core samples' test data, 9 inclinometer data and 12 groundwater level measurements. In the concept of present work, a number of 8 core data, laboratory data and the results of inclinometer measurements in 5 wells were used (Figure 1).

\footnotetext{
${ }^{*}$ Corresponding author/Yazışılan Yazar
} 


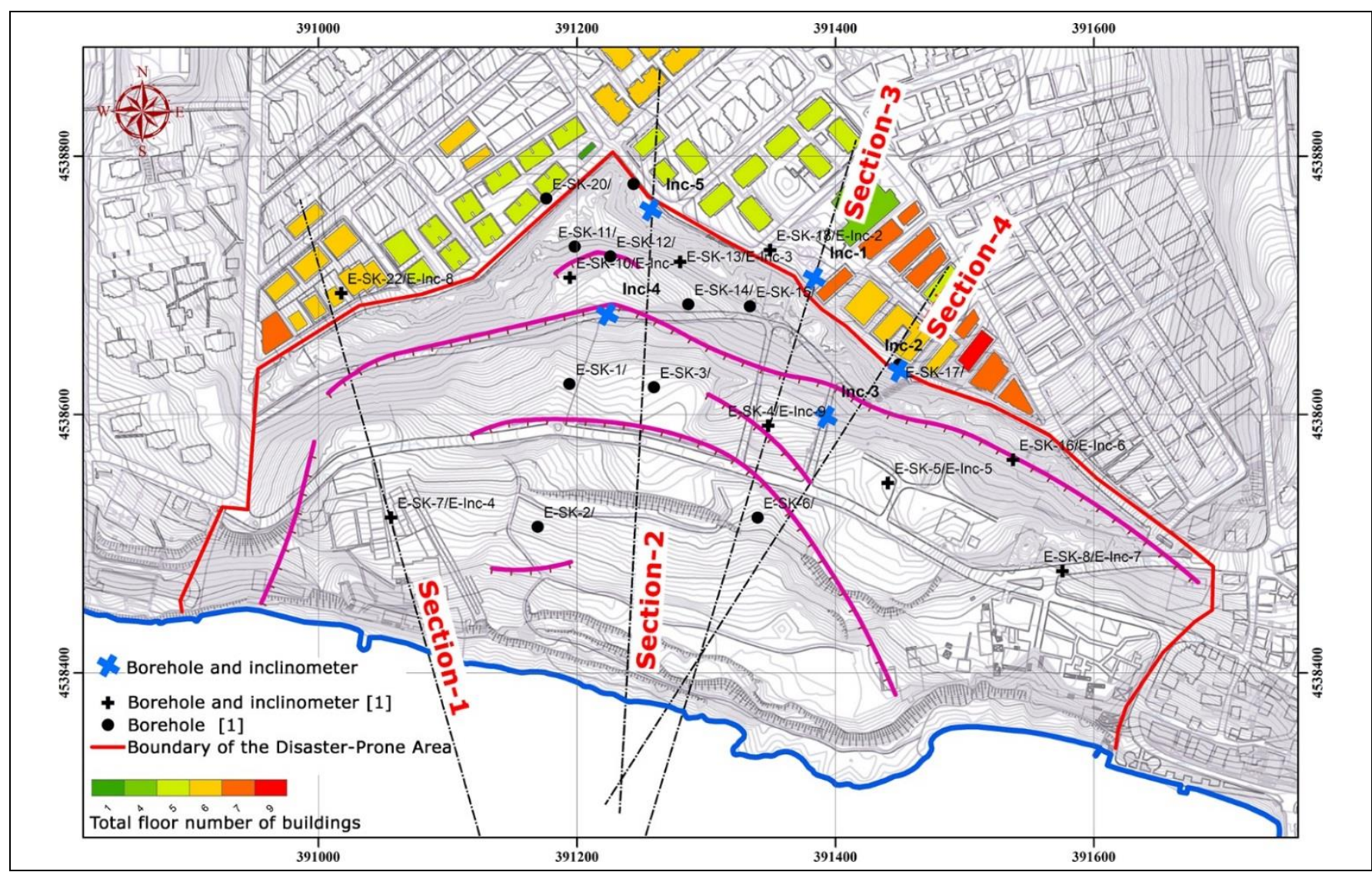

Figure 1. Borehole and inclinometer measurement points, section lines, surface ruptures of landslide in the study area (modified from Güler et al. [1]) and total floor number of buildings in the impact area.

\section{Engineering geology of landside area}

The Avcılar Ambarlı landslide affects an area of $216.000 \mathrm{~m}^{2}$ with length of about $700 \mathrm{~m}$ and width of $350 \mathrm{~m}$. The study area has an inclined morphology toward the Sea of Marmara at south from the ridge extending along the D100 highway at north. In the Disaster-Prone Area that is represented by paleo landslide topography, elevations are between 0 and $45 \mathrm{~m}$. The slope at crown of landslide is in the range of 30 to $60 \%$ whilst slope at accumulation, depression and flow parts of the landslide have slope of 5 to $10 \%$. The bathymetry of the Sea of Marmara along an-550 m traverse at the south of landslide area has been investigated by [1] and the average slope of seafloor was found as $2.25 \%$. The absence of data on the landslide at the seafloor is attributed to their destruction by marine currents. The major slip plane is traced by sudden topographic differences and ongoing deformations along north and western boundaries of the area.

In the study area there is an artificial fill material of $6 \mathrm{~m}$ thickness. The artificial fill is composed of clay-sand with concrete and asphalt fragments, in some parts concrete blocks from demolished buildings underlain by sand-clay with concrete fragments as well as pebble, clay and silt-size materials in some other parts. The artificial fill is underlain by light brown, moderately firm-firm, clay-silty clay units $(\mathrm{CH})$ of the Cekmece formation. In the area, the Cekmece formation is locally represented by limestone, marl and silty sand interlayers (SM). The contact of this unit with the Danişmen formation is characterized by clayey gravel or gravelly clay levels. Below the Çekmece formation are green-light brown, partly gravelly, tuff interlayered firm-compact clay $(\mathrm{CH})$ levels of the Danișmen formation (Figure 2). In the Disaster-Prone Area, Danişmen formation-Çekmece formation are mostly bordered by slip plane. In the study area, groundwater depth is between $7.0 \mathrm{~m}$ and $10.0 \mathrm{~m}$.

Landslides in the area were formed during the glacial periods in the Pleistocene by extensions triggered by deep carvings within the valleys as the valley scarps could not maintain their stability due to deepening and steepening of valleys [3]. The 17 August 1999 earthquake seriously affected the Avcllar region [4]. As a result, it is thought that the studied old landslide was reactivated during the 2004 spring due to weakening of residual soil parameters in about 5 years.

According to [1], the studied landslide reactivated during the 2004 spring and primary slip planes were recorded on the surface in a limited area at north of the landslide. The fractures on the primary slip planes continued to grow and until December of this year fractures new fractures were formed at north of the landslide. At the end of January 2005, another slip plane with SE trend was detected at south of the landslide. At the end of February 2005, a third slip plane appeared at NW of primary slip plane. By the end of 2005, a displacement up to 1 $m$ was found on the surface trace of slip plane along the northern part of area while displacement on the surface rupture at the south was measured as $1.20 \mathrm{~m}$. 


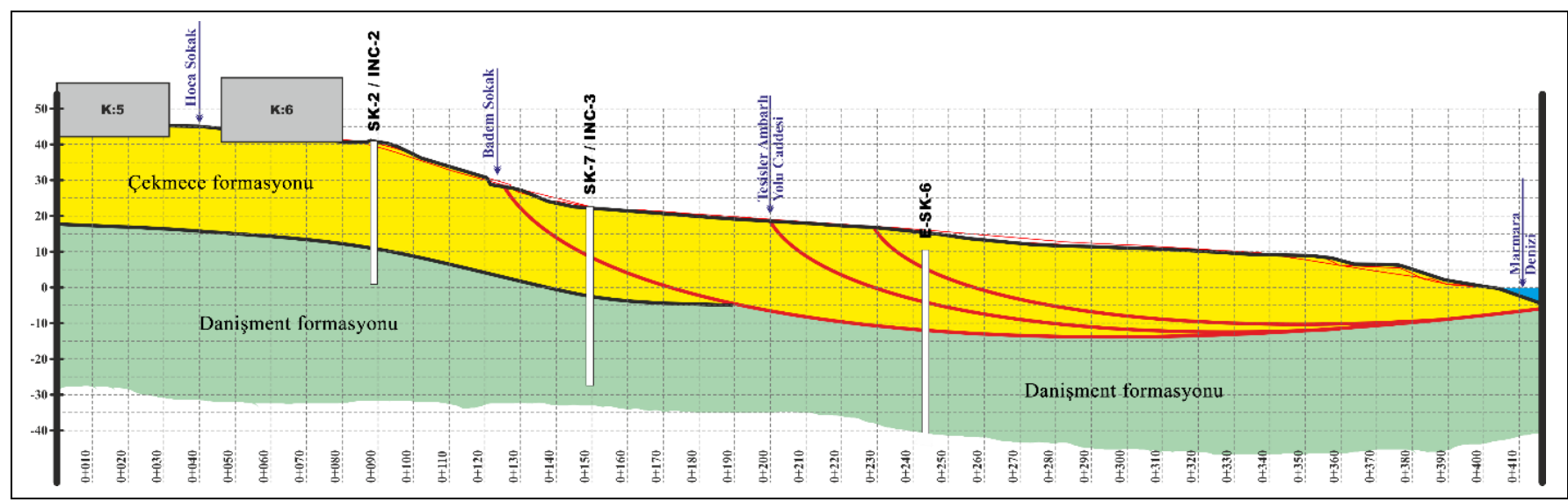

Figure 2. Simplified geologic section of landslide area along the section-4.

\section{Geotechnical studies and evaluation}

During the drilling, standard penetration and pressuremeter tests were conducted. In the concept of this study, water content, unit weight, Atterberg limits, grain size distribution, cohesion and angle of internal friction were determined for 57 disturbed and undisturbed samples collected from eight boreholes. Moreover, results of inclinometer measurement and stability analysis carried out in the area were also evaluated.

\subsection{Field and laboratory tests}

In the Standard penetration tests, 13 lowest SPT $\mathrm{N}_{30}$ values were obtained from clay and clayey-silty levels and 29 lowest SPT $\mathrm{N}_{30}$ values from gravelly units of the Cekmece formation. Regarding the Danișmen formation, 24 lowest SPT $\mathrm{N}_{30}$ values were obtained from clay and clayey-silty levels and 26 lowest SPT $\mathrm{N}_{30}$ values from the pebbly units. The highest SPT $\mathrm{N}_{30}$ values are found $>50$ for all formations and lithologies. In the pressuremeter tests conducted by Güler et al. [1], a number of 20 tests were made at five points at depths between $7.5 \mathrm{~m}$ and $63.0 \mathrm{~m}$ and net limit pressure of soils is found as 460 to $2580 \mathrm{kN} / \mathrm{m}^{2}$.

Using the laboratory data soils are classified (as minimum, maximum and average values) on the basis of lithology type and the results are given in Table 1-Table 3.

Although results from index tests indicate no significant difference to affect the stability analysis, uniaxial compression test yielded noteworthy differences in the undrained shear strength. At undrained conditions, the peak cohesion value (cu) is found $81.6 \mathrm{kN} / \mathrm{m}^{2}$ for the Çekmece formation and $146.6 \mathrm{kN} / \mathrm{m}^{2}$ for the Danişmen formation (Table 3). In this study, using the field and laboratory data, geologic sections were established in 4 different directions to review the landslide mitigation efforts and to make 3-D assessment of the field. Section- 4 has been selected as a representative to indicate the soil structure, landslide mechanism and the most critical stability conditions of the area. The routes selected are given in Figure 1 and the geologic sections are shown in Figure 2. The total and effective parameters used in the stability analysis are given in Table 4. In the selection of these parameters, results of laboratory tests, back analysis method and empirical method of Gibson [5] were used.

\subsection{Assessment of inclinometer measurements}

In the study area, inclinometer measurements were conducted for 14 boreholes at two different periods; by [1] in February 2005-March 2005 and in December 2018-March 2019 within this study. As a result of the measurements, slip planes have been determined by Güler et al. [1] at depths ranging from 13.0 $\mathrm{m}$ to $40.0 \mathrm{~m}$ with displacements of up to $100 \mathrm{~mm}$. In the area, it is stated that the movement speeds are between $2 \mathrm{~mm} /$ day and $5 \mathrm{~mm} /$ day [6].

Inclinometer measurements conducted for 5 boreholes in the frame of this study yielded slip planes at depths between $5.0 \mathrm{~m}$ and $24.0 \mathrm{~m}$. The slip determined at a depth of $5.0 \mathrm{~m}$ in borehole Inc- 1 outside of landslide area occurs in the artificial fill at the contact of units of the Cekmece formation. In boreholes Inc-3 and Inc-4, 1 and 3 slip planes were observed, respectively. The depth of slip planes is $18.5 \mathrm{~m}$ in borehole Inc-3 and 6, 14 and $24 \mathrm{~m}$ in Inc-4 (Figure 3). The maximum displacements are $10.89 \mathrm{~mm}$ in Inc-1, $4.55 \mathrm{~mm}$ in Inc-2, $53.52 \mathrm{~mm}$ in Inc-3, 75.81 $\mathrm{mm}$ in Inc-4 and $5.46 \mathrm{~mm}$ in Inc-5. According to cumulative displacement velocity estimations, the maximum displacement rate is $0.086 \mathrm{~mm} /$ day in Inc- $1,0.037 \mathrm{~mm} /$ day in Inc-2, 0.397 $\mathrm{mm} /$ day in Inc-3, $0.549 \mathrm{~mm} /$ day in Inc- 4 and $0.044 \mathrm{~mm} /$ day in Inc-5. The movements are toward the hillside slope and the average values are $172^{\circ} \mathrm{K}$ in Inc- $1,207^{\circ} \mathrm{K}$ in Inc- $2,205^{\circ} \mathrm{K}$ in Inc$3,62^{\circ} \mathrm{K}$ in Inc- 4 and $260^{\circ} \mathrm{K}$ in borehole Inc-5.

In geologic sections slip planes are shown to have a depth of $30.0 \mathrm{~m}$. The crown line appears in an arc-shape with large diameter and slip surface is semi-spherical shaped. Considering its impact area, the landslide is classified as "very large landslide" [7]. According to landslide velocity classification of [8], the landslide with rate of $5 \mathrm{~mm} /$ day is of extremely rapid type [1]. During the December 2018-May 2019 period, the velocity in borehole Inc-1 that is outside the Disaster-Prone Area is found very slow whereas the velocity in boreholes Inc2 and Inc- 5 is extremely slow. In boreholes Inc- 3 and Inc- 4 in the disaster-prone area block velocities were found very low. Estimations showed that the movements in the area have very low velocity whereas those outside the area have extremely low velocity. Observation of movement at further north of the known landslide boundary might indicate that a regressivetype landslide mechanism affects the study area. 
Table 1. Natural water content of soils, gravel, sand and silt+clay percent, liquid limit, plastic limit, plasticity index, name of formation and soils groups.

\begin{tabular}{|c|c|c|c|c|c|c|c|c|}
\hline \multirow{3}{*}{ Depth (m) } & \multirow{3}{*}{$\begin{array}{l}\mathrm{Wn}_{\mathrm{n}} \\
(\%)\end{array}$} & \multicolumn{3}{|c|}{ Sieve analysis } & \multicolumn{3}{|c|}{ Atterberg limits } & \multirow{3}{*}{ Formation / Soil Class } \\
\hline & & & Sand & $\begin{array}{l}\text { Silt + } \\
\text { Clay }\end{array}$ & $\mathrm{W}_{\mathrm{L}}$ & $W_{P}$ & $\mathrm{IP}$ & \\
\hline & & $(\%)$ & $(\%)$ & $(\%)$ & $(\%)$ & $(\%)$ & $(\%)$ & \\
\hline Number of samples & 33 & 22 & 22 & 22 & 23 & 20 & 20 & \multirow{5}{*}{ Çekmece / (CH, SM, GC) } \\
\hline Minimum & 10.20 & 0.00 & 1.63 & 4.34 & 25.00 & 21.30 & 3.70 & \\
\hline Maximum & 31.60 & 45.53 & 95.66 & 98.37 & 64.10 & 27.30 & 38.40 & \\
\hline Standard deviation & 6.45 & 9.50 & 30.14 & 33.52 & 9.30 & 1.71 & 7.83 & \\
\hline Mean & 26.17 & 2.55 & 18.42 & 79.04 & 58.60 & 25.50 & 33.10 & \\
\hline Number of samples & 22 & 9 & 9 & 9 & 9 & 8 & 8 & \multirow{5}{*}{ Danișmen / (CH, SP) } \\
\hline Minimum & 13.70 & 0.00 & 1.05 & 4.16 & 27.80 & 17.40 & 10.40 & \\
\hline Maximum & 30.30 & 15.53 & 95.84 & 98.95 & 65.00 & 26.60 & 38.60 & \\
\hline Standard deviation & 3.60 & 5.41 & 32.73 & 34.09 & 12.26 & 2.95 & 9.37 & \\
\hline Mean & 26.79 & 3.16 & 20.50 & 76.34 & 56.66 & 24.54 & 32.13 & \\
\hline
\end{tabular}

Table 2. Natural water content $\left(\mathrm{w}_{\mathrm{n}}\right)$, porosity $(\mathrm{n})$, void ratio $(\mathrm{e})$, and saturation $(\mathrm{S})$, name of formation and soils groups.

\begin{tabular}{|c|c|c|c|c|c|c|c|c|c|c|}
\hline Depth (m) & $\begin{array}{l}W_{n} \\
(\%)\end{array}$ & $\gamma_{\mathrm{n}}$ & $\gamma_{\mathrm{k}}$ & $\frac{\gamma_{\mathrm{s}}}{\left(\mathrm{kN} / \mathrm{m}^{3}\right)}$ & $\gamma_{\mathrm{d}}$ & $\gamma_{\mathrm{A}}$ & $\begin{array}{c}\mathrm{n} \\
(\%)\end{array}$ & $\begin{array}{c}\mathrm{e} \\
(\%)\end{array}$ & $\begin{array}{c}\text { S } \\
(\%)\end{array}$ & Formation / Soil Class \\
\hline Number of samples & 33 & 35 & 35 & 18 & 35 & 35 & 35 & 35 & 35 & \\
\hline Minimum & 10.20 & 18.2 & 14.3 & 25.0 & 18.7 & 8.7 & 34.78 & 53.34 & 48.35 & \\
\hline Maximum & 31.60 & 19.9 & 16.5 & 27.6 & 20.0 & 10.0 & 45.99 & 85.15 & 99.66 & Çekmece / (CH, SM, GC) \\
\hline Standard deviation & 6.45 & 0.5 & 0.6 & 0.9 & 0.4 & 0.4 & 4.19 & 11.72 & 20.51 & \\
\hline Mean & 26.17 & 19.2 & 15.3 & 26.4 & 19.5 & 9.5 & 41.84 & 72.78 & 85.16 & \\
\hline Number of samples & 22 & 22 & 22 & 11 & 22 & 22 & 22 & 22 & 22 & \\
\hline Minimum & 13.70 & 18.2 & 14.8 & 25.2 & 19.2 & 9.2 & 36.69 & 57.94 & 59.68 & \\
\hline Maximum & 30.30 & 20.0 & 16.0 & 27.6 & 19.9 & 9.9 & 45.38 & 83.10 & 99.68 & Danișmen / (CH, SP) \\
\hline Standard deviation & 3.60 & 0.4 & 0.3 & 0.8 & 0.2 & 0.2 & 2.43 & 7.07 & 11.55 & \\
\hline Mean & 26.79 & 19.4 & 15.3 & 26.4 & 19.5 & 9.5 & 42.04 & 72.83 & 91.53 & \\
\hline
\end{tabular}

Table 3. Distribution of cohesion and internal friction angle of soils with respect to lithology determined from uniaxial and triaxial compression tests and shear test

\begin{tabular}{|c|c|c|c|c|c|c|c|c|c|}
\hline \multirow{2}{*}{ Depth (m) } & \multicolumn{2}{|c|}{$\begin{array}{c}\text { Uniaxial } \\
\text { compression test }\end{array}$} & \multicolumn{2}{|c|}{ Shear test } & \multicolumn{2}{|c|}{ Residual shear test } & \multicolumn{2}{|c|}{$\begin{array}{c}\text { Triaxial compression } \\
\text { test }\end{array}$} & \multirow{2}{*}{$\begin{array}{c}\text { Formation / } \\
\text { Soil Class }\end{array}$} \\
\hline & $\begin{array}{c}\mathrm{qu}_{\mathrm{u}} \\
(\mathrm{kPa})\end{array}$ & $\begin{array}{c}\mathrm{c}_{\mathrm{u}} \\
(\mathrm{kPa})\end{array}$ & $\begin{array}{c}\mathrm{c}_{\mathrm{p}} \\
(\mathrm{kPa})\end{array}$ & $\begin{array}{l}\varphi_{\mathrm{p}} \\
(0)\end{array}$ & $\begin{array}{c}\mathrm{c}_{\mathrm{r}} \\
(\mathrm{kPa})\end{array}$ & $\varphi_{\mathrm{r}}$ & $\begin{array}{c}\mathrm{C} \\
(\mathrm{kPa})\end{array}$ & $\Phi$ & \\
\hline Number of samples & 18 & 18 & 17 & 17 & 10 & 10 & 14 & 14 & \multirow{5}{*}{$\begin{array}{c}\text { Çekmece / } \\
(\mathrm{CH}, \mathrm{SM}, \mathrm{GC})\end{array}$} \\
\hline Minimum & 163.21 & 81.61 & 3.23 & 12.18 & 18.71 & 11.36 & 62.29 & 9.83 & \\
\hline Maximum & 591.38 & 295.69 & 147.77 & 26.05 & 79.87 & 20.57 & 185.77 & 18.58 & \\
\hline Standard deviation & 121.11 & 60.55 & 56.39 & 3.75 & 18.17 & 2.38 & 29.55 & 2.69 & \\
\hline Mean & 387.37 & 193.68 & 77.12 & 20.71 & 47.12 & 16.52 & 130.15 & 13.69 & \\
\hline Number of samples & 9 & 9 & 10 & 10 & 9 & 9 & 9 & 9 & \multirow{5}{*}{$\begin{array}{c}\text { Danişmen / } \\
(\mathrm{CH}, \mathrm{SP})\end{array}$} \\
\hline Minimum & 293.20 & 146.60 & 4.73 & 13.23 & 13.72 & 11.24 & 45.65 & 9.50 & \\
\hline Maximum & 665.33 & 332.66 & 163.75 & 26.74 & 96.35 & 19.48 & 203.84 & 20.19 & \\
\hline Standard deviation & 153.50 & 76.75 & 52.73 & 4.19 & 26.03 & 2.63 & 44.65 & 2.85 & \\
\hline Mean & 467.31 & 233.66 & 91.66 & 19.00 & 50.82 & 15.30 & 144.90 & 13.21 & \\
\hline
\end{tabular}

Table 4. Representative geotechnical parameters

\begin{tabular}{|c|c|c|c|c|c|c|c|}
\hline \multirow[b]{2}{*}{ Formation } & \multirow[b]{2}{*}{$\begin{array}{c}\text { Unit } \\
\text { weight } \\
k N / m^{3}\end{array}$} & \multirow[b]{2}{*}{$\begin{array}{c}\text { Saturated } \\
\text { unit weight } \\
k N / m^{3}\end{array}$} & \multicolumn{2}{|c|}{ Static analysis } & \multicolumn{3}{|c|}{ Dynamic analysis } \\
\hline & & & $\begin{array}{c}\text { Cohesion } \\
k N / m^{2}\end{array}$ & $\begin{array}{l}\text { Friction } \\
\text { angle } \\
(0)\end{array}$ & $\begin{array}{c}\text { Cohesion } \\
k N / m^{2}\end{array}$ & $\begin{array}{l}\text { Cohesion } \\
\text { change } \\
\mathrm{kN} / \mathrm{m}^{2} / \mathrm{m}\end{array}$ & $\begin{array}{c}\text { Highest } \\
\text { cohesion } \\
k N / m^{2}\end{array}$ \\
\hline Çekmece & 17 & 18 & 0 & 16 & 80 & 16 & 150 \\
\hline Danișmen & 18 & 19 & 0 & 25 & 146 & 20 & 250 \\
\hline
\end{tabular}



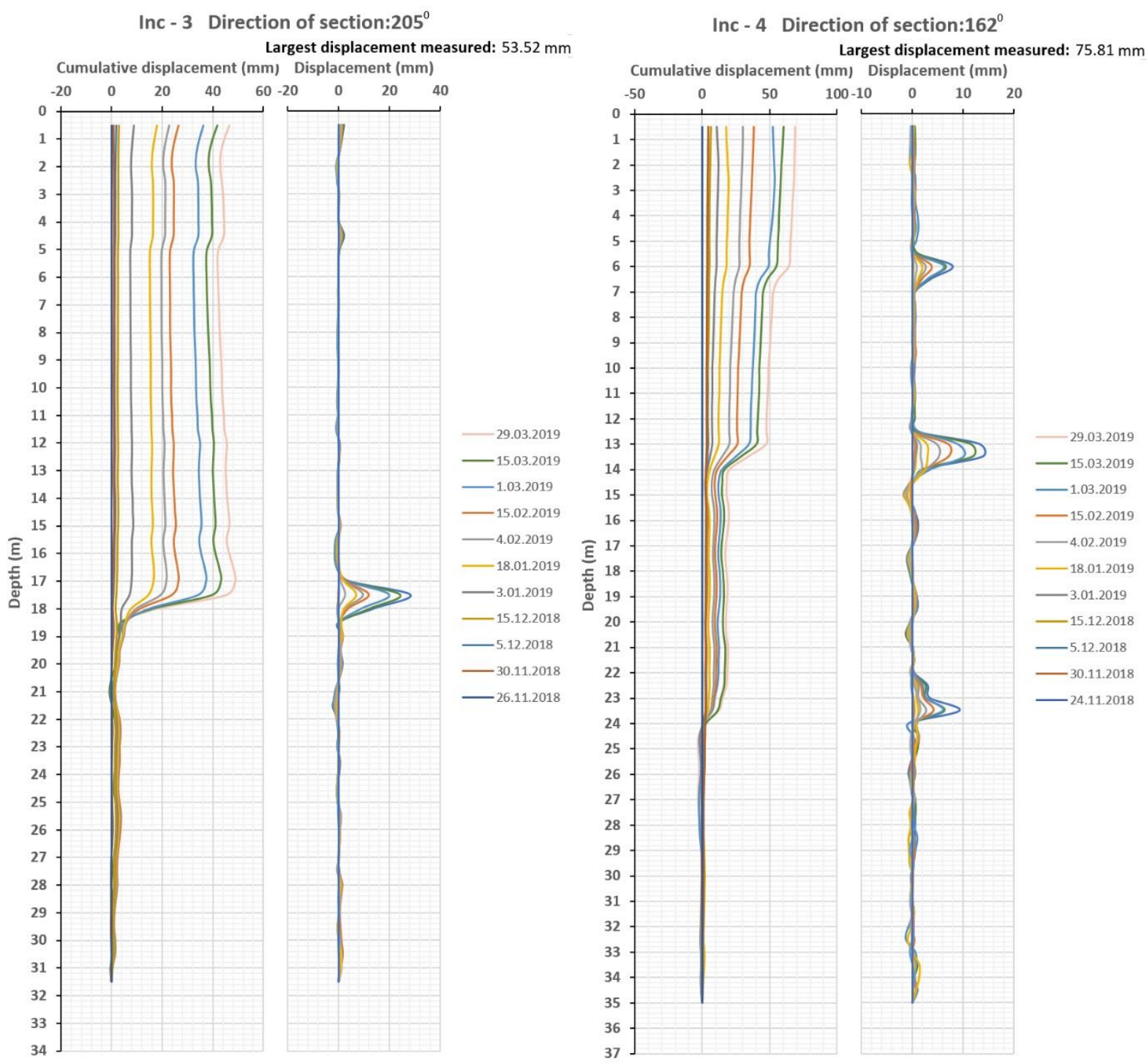

Figure 3. Inc-3 and Inc-4 depth-displacement graphics.

\subsection{Stability analysis}

In the study area, using the geotechnical parameters given in Table 4, a stability analysis was made for the area at the northern border of disaster-prone area. The analyses were repeated by the proposed support system and the variation was described at safety conditions. In the analysis, Slide 6.0 software was used that runs limit equilibrium Bishop method. In the analysis, total story numbers of buildings in the impact area of regressive-type landslide were used and a load of $20 \mathrm{kN}$ was taken for each story. In pseudo-static case analysis, peak ground acceleration was assigned as $\mathrm{PGA}=0.534 \mathrm{~g}$ and thus horizontal and vertical seismic load coefficients were taken as 0.27 and 0.13 , respectively. The safety coefficients obtained were evaluated with respect to TS 8853 criteria and safety coefficient limit for the static and dynamic cases are found as $\mathrm{FS}=1.5$ and $\mathrm{FS}=1.1$.

The stability analysis was carried out separately for static and pseudo-static cases and it was found that at both conditions some areas do not fulfil the safety criteria. Results obtained for
4 different analysis cases are shown in Table 5 and representative sections are given in Figure 4. Results of analysis indicate that stability problems along the Section-1, Section- 2, Section- 3 and Section-4 extend outside the Disaster-Prone Area (Table 5). Results of stability analysis carried out at north of Disaster-Prone Area indicate that roads and buildings in this site are seated on soils with stability problems. This is also supported by velocities estimated by surface ruptures of slip planes, ongoing deformations and displacements revealed by inclinometer measurements.

In this study, bored pile element structure was taken into consideration that is applicable for maintaining the stability. In the selection of the location and depth of the bored piles, it is aimed not to stop the landslide, but to prevent the landslide from regressing and not affecting the stability of the structures. Therefore, the system designed to be applied piles, which is diameter of $120 \mathrm{~cm}$ and length of $30 \mathrm{~m}$, on the boundary of Disaster-Prone Area. The shear strength of the piles used $1300 \mathrm{kN} / \mathrm{m}$ in the stability analysis. The analysis was repeated for static and pseudo-static conditions using new models 
established by the proposed rehabilitation method, the results obtained are given in Table 5 , and representative section is shown in Figure 4. Results of analysis carried out proposed rehabilitation method reveal that Section-1, Section-2 and Section- 4 at static condition and Section- 3 at dynamic condition do not fulfil the safety criteria. However, safety coefficients estimated lower than necessary limits and possible slip circles determined by these coefficients are within the Disaster-Prone Area. Considering the northward border of Disaster-Prone Area, results of analysis indicate that proposed bored pile system yielded successful results to increase the stability conditions.

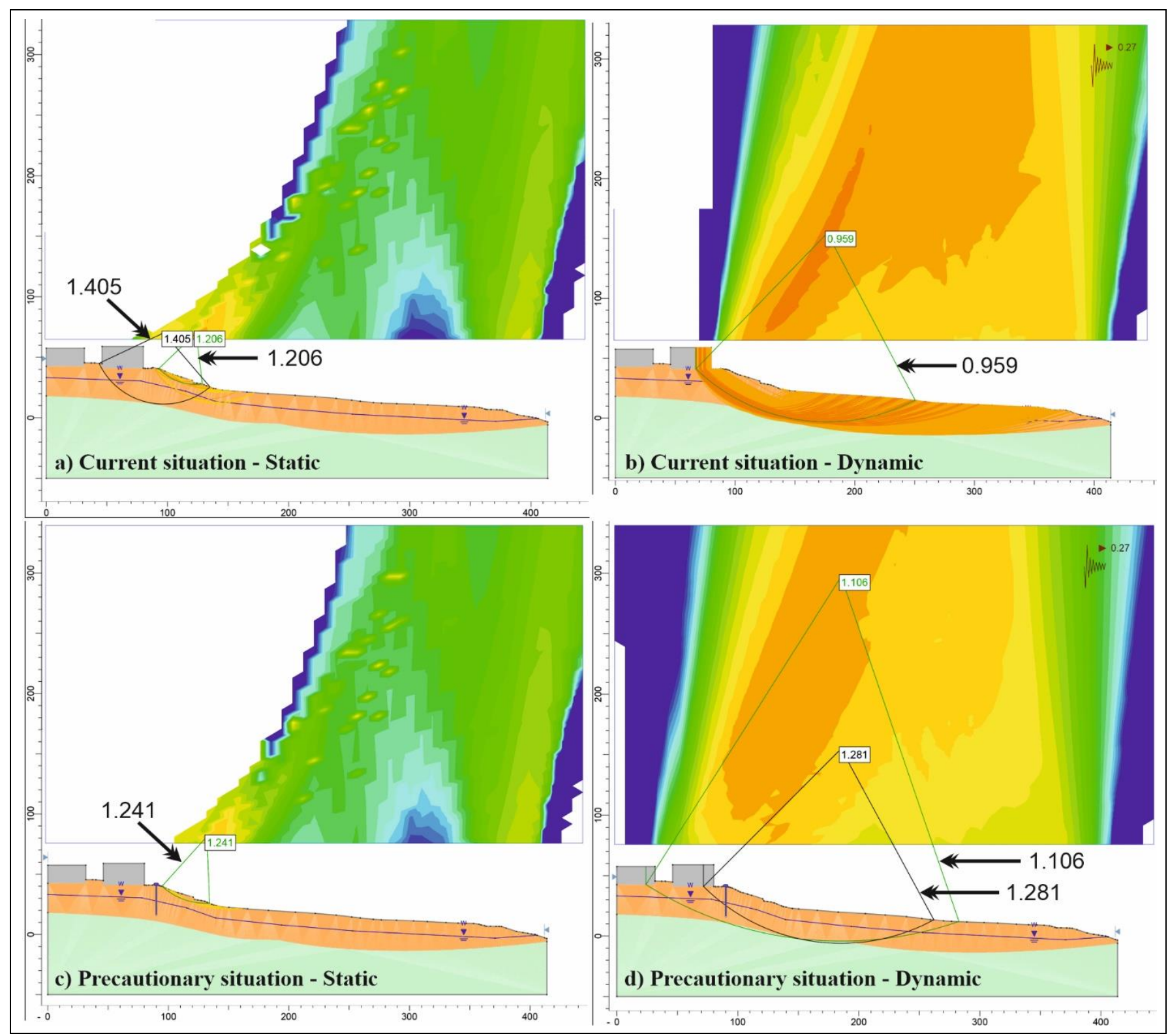

Figure 4. For current and precautionary situations static and dynamic stability analyses along the Section -4 .

Table 5. Results of stability analysis and factor of safety.

\begin{tabular}{|c|c|c|c|c|c|c|}
\hline \multirow[b]{2}{*}{ Section Number } & \multicolumn{3}{|c|}{ Current Situation } & \multicolumn{3}{|c|}{ Precautionary Situation } \\
\hline & $\begin{array}{l}\text { Static } \\
(F S)\end{array}$ & $\begin{array}{c}\text { Pseudo-static } \\
\text { (FS) }\end{array}$ & Security issue* & $\begin{array}{l}\text { Static } \\
(F S)\end{array}$ & $\begin{array}{c}\text { Pseudo-static } \\
\text { (FS) }\end{array}$ & Security issue \\
\hline Section - 1 & 1.26 & 0.81 & Yes & $1.26^{* *}$ & 1.16 & No \\
\hline Section -2 & 1.11 & 0.98 & Yes & $1.11^{* *}$ & 1.13 & No \\
\hline Section -3 & 1.04 & 0.10 & Yes & 1.51 & $1.06^{* *}$ & No \\
\hline Section -4 & 1.20 & 0.95 & Yes & $1.24^{* *}$ & 1.10 & No \\
\hline
\end{tabular}

* Security issue: There is or no stability problem outside boundary of the Disaster-Prone Area.

** Safety factor of slip surface within the Disaster-Prone Area. 


\section{Results}

This study was carried out to investigate the negative impacts of İstanbul Avcılar Ambarlı landslide to the buildings along its northern border. In the area, the landslide mass currently moves southward with slow rates that emerged in 2005 because of deformations causing structural damage. The movements on the Çekmece formation outside the landslide area at north of crown part are extremely low with velocity of $0.5 \mathrm{~mm} / \mathrm{month}$ whereas velocity attains a rate of 2.5 $\mathrm{mm} / \mathrm{month}$ in areas covered with artificial fill. Velocity in the landslide area was found $15 \mathrm{~mm} / \mathrm{month}$ for the artificial fill and $9 \mathrm{~mm} /$ month for the underlying bedrock soil. Static and dynamic stability analyses indicate that factor of safety values are as low as 1.0 which cannot fulfill the necessary safety conditions at north of the landslide area. In north of Avclar Landslide that is represented by a regressive-type landslide mechanism, for the existing buildings loss of life and property will be inevitable if necessary precautions are not taken. On the northern border of landslide area, which has been declared as a Disaster-Prone Area, a system composing of bored piles with diameter of $120 \mathrm{~cm}$ and $30 \mathrm{~m}$ length might increase the safety coefficient more than 1.5 for static condition and 1.1 for pseudo-static condition. Therefore, based on limit equilibrium analysis, bored pile system proposed in this study is found to be effective to increase safety conditions of northern part above the required safety limit values. Stress-deformation condition of the proposed bored pile system under horizontal soil pressure was reviewed and it is suggested that before taking any measurement this matter must be taken into consideration.

\section{Kaynaklar}

[1] Güler E, Yüzer E, Eyidoğan H, Gürbüz C, Öngür T, Osmanoğlu U, Oran S, Bingöl H. "İstanbul Avcılar İlçesi Ambarlı Mahallesi Güneyindeki Zemin Hareketlerine Yönelik (Ayrıntılı Jeolojik-Jeoteknik) Duraylılık Etüdü". ELC Group Mühendislik ve Müşavirlik Ltd. Şti, İstanbul, Türkiye, 156, 2005.
[2] Dalgıç S, Turgut M, Kuşku İ. "Büyükçekmece ile Küçükçekmece arasındaki heyelanların oluşmasında hazırlayıcı ve tetikleyici parametrelerin değerlendirilmesi". Uygulamalı Yerbilimleri Dergisi, 2, 56-73, 2010.

[3] Arpat E. "Büyükçekmece ile Küçükçekmece (İstanbul) heyelanlarının genel özellikleri ve yarattıkları başlıca sorunlar". 52. Türkiye Jeoloji Kurultayı, Ankara, Türkiye, 10-12 Mayıs 1999.

[4] Dalgıç S. "Factors affecting the greater damage in the Avcllar area of Istanbul during the 17 August 1999 Izmit earthquake". Bulletin of Engineering Geology and the Environment, 63(3), 221-232, 2004.

[5] Gibson RE. "Experimental Determination of the True Cohesion and True Angle of Internal Friction in Clay". ISSMFE $3^{\text {rd }}$ International Conference, Zurich, Switzerland, 15 August 1953.

[6] Yüzer E, Güler E, Baş M, Osmanoğlu U. "İstanbul Avcılar Ambarlı heyelanının kinematiği”. Istanbul'un Jeolojisi Sempozyumu II, İstanbul, Türkiye, 16-18 Aralık 2005.

[7] Cornforth D. Landslides in Practice: Investigation, Analysis, and Remedial/Preventative Options in Soils. New York, USA, Wiley, 2005.

[8] Cruden DM, Varnes DJ. Landslide Types and Processes. Editors: Turner AK, Schuster RL. In Landslides: Investigation and Mitigation, 36-75, USA, Transportation Research Board, 1996. 